From the Department of Medicine 1, Swedish University of Agricultural Sciences, Uppsala, Department of Endocrinology, Karolinska Hospital, Stockholm, Laboratory of Comparative Pathology, Stockholm and Department of Clinical Chemistry, Karolinska Hospital, Stockholm, Sweden.

\title{
Hypophosphatemia Induced by Dietary Aluminium Hydroxide Supplementation in Pigs: Effects on growth, blood variables, organ weights and renal morphology*
}

\author{
By L. Håglin, B. Essén-Gustavsson, A. Kallner, A. Lindholm, S. Reiland and H. E. Sjöberg
}

\begin{abstract}
Håglin, L., B. Essén-Gustavsson, A. Kallner, A. Lindholm, S. Reiland and H. E. Sjöberg: Hypophosphatemia induced by dietary aluminium hydroxide supplementation in pigs: Effects on growth, blood variables, organ weights and renal morphology. Acta vet. scand. 1988, 29, 91-99. - Twenty-four pigs, 13-14 weeks of age, were studied during an experimental period of 10 weeks. The pigs were randomly divided into 3 groups. Two groups were fed a commercial feed supplemented either with a suspension of aluminium hydroxide $\left(\mathrm{Al}(\mathrm{OH})_{3}\right)$ or aluminium phosphate $\left(\mathrm{AlPO}_{4}\right)$. The third group served as a control. The same total amount of aluminium was given to each of the 2 experimental groups. After three weeks the $\mathrm{Al}(\mathrm{OH})_{3}$-pigs developed severe hypophosphatemia, with an average decrease in serum phosphate of $60 \%$, a decreased growth rate and a lower concentration of 2,3-diphosphoglycerate in the erythrocytes as compared to controls. Intense hypercalcemia developed in the $\mathrm{Al}(\mathrm{OH})_{3}$-group during the first 6 weeks, whereas the $\mathrm{AlPO}_{4}$-pigs and the control group developed neither hypophosphatemia nor hypercalcemia. At necropsy, the consequence of the long lasting hypophosphatemia was found to be increased relative kidney weights with morphological signs of tubular damage and dyscalcification. No similar changes were observed in the $\mathrm{A} \mathrm{PO}_{4}$-groups and there were no organ weight deviations compared to the control group.
\end{abstract}

hypercalcemia; aluminium; 2,3-diphosphoglycerate; nephrosis.

\section{Introduction}

Effects of hypophosphatemia have recently received attention in human medicine (Fitzgerald 1978, Jacob 1975). In veterinary medicine effects of hypophosphatemia have

\footnotetext{
*Supported in part by the Swedish Medical Research Council (grant no. 05992), the funds of the Karolinska Institute, the Swedish University of Agricultural sciences and Swedish Council for Forestry and Agricultural research.
}

previously been documented in ruminants, for review, see Theiler et al. (1932). Principally, 3 main causes for the development of severe hypophosphatemia have been demonstrated: A shift of phosphate from the extracellular to the intracellular space (e.g., that induced by hyperalimentation), renal phosphate losses and decreased phosphate absorption from the intestine (Silvis \& Paragas 1971, Emmett \& Seldin 1978, Knochel 1981). Phosphate depletion has been induced in 
rats (Day \& McCollum 1939, Davis et al. 1979, Schwarz et al. 1985) and in dogs (Fuller et al. 1978) by giving aluminium hydroxide or aluminium carbonate and-/or a low phosphate feed. In pigs, only a few experimental studies have used a phosphate deficient diet (Aubel et al. 1936, Filer et al. 1966), although dietary phosphorus recommendations for growing swine are based on studies of biological characteristics at different levels op phosphorus intake (Koch \& Mahan 1985). By supplementing a nonpurified diet with aluminium hydroxide, phosphate is lost through the feces and therefore escapes absorption (Spencer et al. 1982, Knochel 1982).

The aim of the present investigation was to study the consequences of hypophosphatemia in growing pigs. $\mathrm{A} 1(\mathrm{OH})_{3}$ was given as supplement to the feed and $\mathrm{A} \mathrm{PO}_{4}$ was given to a second group as a form of a control group supplemented with aluminium and phosphate. For comparison, a third group of pigs was studied with no supplement added to the feed. The parameters studied were growth rate, organ weights, blood variables such as inorganic phosphate, calcium and 2,3-diphosphoglycerate in erythrocytes, as well as renal morphology.

\section{Materials and methods}

Twenty-four Swedish Landrace pigs (13-14 weeks old) weighing from 20 to $42 \mathrm{~kg}$ were randomly divided into 3 groups. Live weights were recorded every 10 days during the 10 weeks experimental period and daily weight gain was calculated. The pigs were kept in pairs in concrete pens, and fed a commercial nonpurified diet twice daily. The composition of the feed and the calculated nutrient content are listed in Table 1 . The first group was given aluminium hydroxide $\left(\mathrm{Al}(\mathrm{OH})_{3}\right.$-group) and the second was given aluminium phosphate (A1 $\mathrm{PO}_{4}$-group), both
Table 1. Composition of the feed and calculated content of nutrients.

\begin{tabular}{lc}
\hline Ingredients & Percentage \\
\hline Wheat & 20 \\
Rye & 10 \\
Barley & 60 \\
Soybean meal & 3 \\
Fishmeal & 2 \\
Meat and bone meal & 2 \\
Monocalcium phosphate & 0.3 \\
Sodium chloride & 0.3 \\
Vitamins and minerals $a$ & \\
Calculated nutrient content & \\
ME, MJ/kg & \\
Crude protein (CP), \% & 12.5 \\
Digestible CP, \% & 13.8 \\
Fat, \% & 11.7 \\
N-free extractives (NFE), \% & 2.1 \\
Crude fibre (CF), \% & 53.4 \\
\hline
\end{tabular}

$a$ Supplies per kg feed mixture: 3000 IU vitamin A (Retinol, Roche Rovimix A-500); 400 IU vitamin D (Cholecalciferol, Rovimix $\left.D_{3}-500\right) ; 8$ mg vita$\min \mathrm{E},(\alpha-$ Tocopherol, Rovimix (50\%); $2.5 \mathrm{mg}$ riboflavin; $6 \mathrm{mg}$ Ca-pantothenate; $8 \mathrm{mg}$ niacin; 2 mg pyridoxine; $20 \mathrm{mg} \mathrm{Fe} ; 4 \mathrm{mg} \mathrm{Cu} ; 20 \mathrm{mg} \mathrm{Mn} ; 60$ mg Zn; $100 \mu \mathrm{g}$ Se. KNZ:s Akzo Zout Chemie Svenska AB:s Jodvaccum salt.

in suspension well mixed with the feed. Each pig was given $500 \mathrm{ml}$ per day $(250 \mathrm{ml} / \mathrm{meal})$ of a suspension of $\mathrm{Al}(\mathrm{OH})_{3}$ or $\mathrm{A}_{1 \mathrm{PO}_{4} \text { con- }}$ taining 17.5 and 16.2 grams aluminium, respectively. The third group constituted the control. Castrated male and female pigs were distributed as 5:3, 4:4 and 6:2 in the three groups. The daily feed allowances for week 0-3, 4-6 and 7-10 were $1 \mathrm{~kg}, 1.5 \mathrm{~kg}$ and 2.0 $\mathrm{kg} / \mathrm{pig} /$ day respectively. In addition, the activity and behavior of the animals were observed.

Blood samples were drawn at the beginning of the experiment, after 3 weeks, after 6 weeks and immediately before sacrifice at 10 weeks. Blood samples were obtained from the cranial vena cava under anesthesia with 
Sodium Pentothal ${ }^{\otimes}$ (Abbot Laboratories Chicago Ill., North USA). Serum phosphate was measured by a method based on the reduction of a phosphomolybdic acid complex with ammonium-iron(II)-sulfate (Goldenberg \& Fernandes 1966), and total calcium was determined colorimetrically after the formation of a complex with ocresolphtalein in alkaline medium (Roy Sarkar \& Chauhan 1967). The total error in these methods was 3.5 and $1.7 \%$ respectively.

Erythrocyte 2.3-diphosphoglycerate (2.3DPG) was measured using a kit (Boehringer Mannheim AG, Mannheim, W Germany) based on the method of Ericson \& DeVerdier (1972). The animals were killed by exsanguination through the carotid arteries while under intravenous anesthesia with Sodium Pentothal ${ }^{\otimes}$, and a complete necropsy was performed. Macroscopic findings were noted and the organ weights were recorded. The relative organ weight (organ weight in $\mathrm{g}$ per $100 \mathrm{~g}$ live weight) was calculated proportional to body weight. Samples from a large number of organs were preserved in buffered neutral $3.7 \%$ formaldehyde solution. Specimens from the kidneys were embedded in paraplast (Lancer Sherwood, Medical Industries Ltd, Sussex, England), sectioned at 4-6 $\mu$ and stained with hematoxylin and eosin (HE), PAS and according to the Van Kossa method.

\section{Statistics}

Analysis of variance, followed by pairwise group mean comparisons using Duncan's ttests, was used to assess group differences for the blood samples and for the absolute and relative organ weights ( $S A S$ 1985). Correlation coefficients were computed according to Armitage (1974). The procedure GLM in the SAS ${ }^{\circledR}$ package was used ( $S A S$ 1985). The values given here are mean \pm SEM.
Results

Weight gain

Average weight gains for the 10 week experimental period were significantly lower in the $\mathrm{Al}(\mathrm{OH})_{3}(18.8 \pm 1.4 \mathrm{~kg})$ than in the $\mathrm{A} 1 \mathrm{PO}_{4}$ $(37.7 \pm 1.8 \mathrm{~kg})$ and control groups $(44.5 \pm$ 3.7) ( $\mathrm{p}<0.05)$, (Table 2 for daily weight gain).

Table 2. Daily weight gain (g) in $\mathrm{Al}(\mathrm{OH})_{3}$-group, $\mathrm{A} \mathrm{PO}_{4}$-group and control pigs during 3 periods of the 10 week experimental period.

\begin{tabular}{llllll}
\hline Weeks $\mathrm{A} 1(\mathrm{OH})_{3}$ & \multicolumn{3}{c}{$\begin{array}{c}\mathrm{A}^{2} \mathrm{PO}_{4} \\
(\mathrm{~g} / \text { day }\end{array}$} \\
\hline $0-3$ & $226 \pm 16$ & $* *$ & $438 \pm 49$ & $* *$ & $518 \pm 71$ \\
$3-6$ & $220 \pm 21$ & $* *$ & $458 \pm 53$ & $* * *$ & $554 \pm 55$ \\
$6-10$ & $364 \pm 47$ & $* * *$ & $674 \pm 52$ & $* * *$ & $783 \pm 76$ \\
\hline
\end{tabular}

Values are mean \pm SEM

$* *=\mathrm{p}<0.01$

$* * *=p<0.001 \quad$ based on ANOVA

All pigs exhibited normal appetite at the beginning of the experiment. After 3 weeks, the $\mathrm{Al}(\mathrm{OH})_{3}$ pigs became depressed, their appetite declined and they only consumed about $75 \%$ of the feed allowance. After 6 weeks, the appetite loss was marked, and the pigs consumed only about $50 \%$ of the feed provided.

\section{Blood analysis}

Serum phosphate in the $\mathrm{Al}(\mathrm{OH})_{3}$-group at 3 weeks was significantly lower than in the $\mathrm{AlPO}_{4}$ and control groups ( $\mathrm{p}<0.001$ ), and was correlated with body weight at 10 weeks ( $r=0.59, p<0.01)$, and also inversely correlated with relative renal weight $(r=0.73$, $\mathrm{p}<0.001$ ) (Figure $1 \mathrm{a}$ ).

Serum calcium increased in the $\mathrm{A} 1(\mathrm{OH})_{3}$ treated pigs, and reached a maximum concentration after 6 weeks (Figure 1 b). Serum levels of phosphate and calcium were inver- 


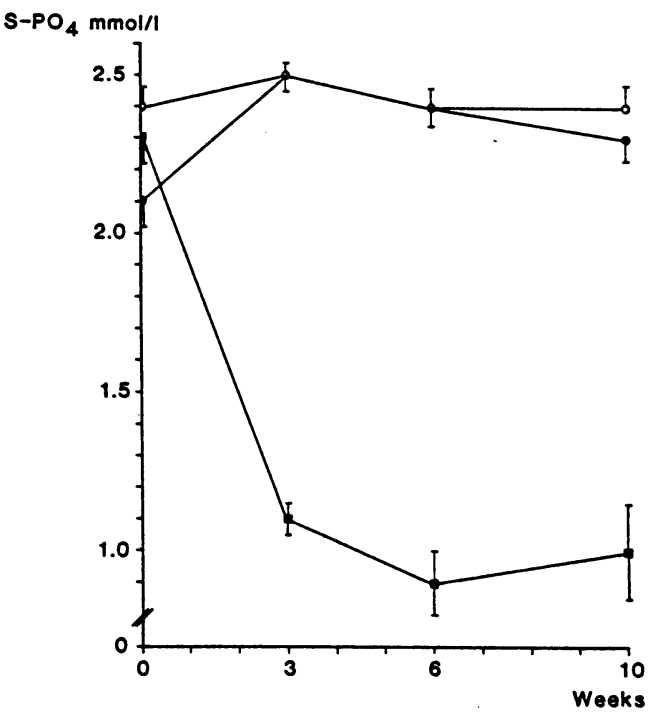

Figure Ia. Mean \pm SEM for serum inorganic phosphate $(\mathrm{mmol} / \mathrm{l})$ at $0,3,6$ and 10 week for $\left(\mathrm{A} 1(\mathrm{OH})_{3^{-}}=\boldsymbol{\square}\right.$ and $\mathrm{AlPO}_{4^{-}}=\boldsymbol{0}$ and control group $=\mathrm{O}$

sely correlated $(r=0.87, p<0.001)$. The correlation between the increase in calcium levels (Ca initial - Ca max) and the minimum phosphate level during the experimental period was $r=0.91(p<0.001)$.

2,3-DPG concentration in erythrocytes was lower in the $\mathrm{A} 1(\mathrm{OH})_{3}$-group after 3, 6 and 10 weeks than in the other 2 groups $(p<0.001)$ (Table 3) and the level of 2,3-DPG was correlated to hypophosphatemia $(r=0.87, p$ $<0.001)$.

\section{Organ weights}

Mean absolute and relative organ weights are presented in Table 4. Organ weights were significantly different between the $\mathrm{Al}(\mathrm{OH})_{3}$ group and the other two groups except for spleen, kidney, pancreas, adrenals and thyroids.

The relative kidney weight was higher ( $p$

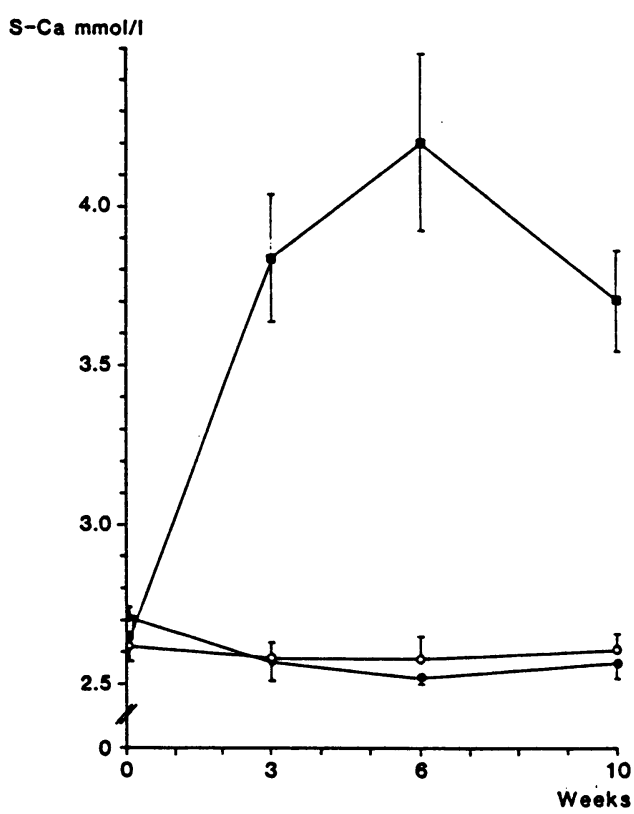

Figure Ib. Mean \pm SEM for total serum calcium $(\mathrm{mmol} / \mathrm{l})$ at $0,3,6$ and 10 week for $\mathrm{Al}(\mathrm{OH})_{3^{-}}=$ and $\mathrm{AlPO}_{4^{-}}=0$ and control group $=0$

$<0.01)$, in the $\mathrm{A} 1(\mathrm{OH})_{3}$-group compared to the other groups. The relative parathyroid weight was lower $(p<0.01)$ compared to the controls.

A correlation was found between relative kidney and relative adrenal weight within the $\mathrm{Al}(\mathrm{OH})_{3}$-group $(\mathrm{r}=0.70, \mathrm{p}<0.001)$.

Table 3. Concentration of 2.3 - diphosphoglycerate in erythrocytes after 3,6 and 10 weeks of the experimental period.

\begin{tabular}{|c|c|c|c|c|c|}
\hline \multicolumn{2}{|c|}{ Weeks $\mathrm{Al}(\mathrm{OH})_{3}$} & \multicolumn{2}{|c|}{$\begin{array}{r}{\mathrm{A} 1 \mathrm{PO}_{4}} \\
(\mathrm{mmol} / \mathrm{L})\end{array}$} & \multicolumn{2}{|r|}{ Control } \\
\hline 3 & $2.7 \pm 01$ & $* * *$ & $3.7 \pm 0.1$ & $* * *$ & $3.7 \pm 0.1$ \\
\hline 6 & $2.7 \pm 0.1$ & $* * *$ & $3.6 \pm 0.1$ & $* * *$ & $3.6 \pm 0.1$ \\
\hline 10 & $2.6 \pm 0.2$ & $* * *$ & $3.7 \pm 0.1$ & *** & $3.9 \pm 0.2$ \\
\hline
\end{tabular}

Values are mean \pm SEM

$* *=\mathrm{p}<0.01$

${ }^{* * *}=\mathrm{p}<0.001 \quad$ based on ANOVA 
Table 4. Organ weights in gram and relative weight in gram $/ 100 \mathrm{~g}$ body weight of pigs fed one of 3 diets for 10 weeks.

\begin{tabular}{lccc|ccc}
\hline Organ & $\mathrm{A} 1(\mathrm{OH})_{3}$ & $\mathrm{AlPO}_{4}$ & Control & $\mathrm{Al}(\mathrm{OH})_{3}$ & $\mathrm{~A} 1 \mathrm{PO}_{4}$ & Control \\
\hline & & $(\mathrm{g})$ & & \multicolumn{3}{|c}{$(\mathrm{g} / 100 \mathrm{~g} \mathrm{BW})$} \\
Spleen & $87 \pm 9$ & $103 \pm 6$ & $106 \pm 17$ & $0.15 \pm 0.01$ & $0.13 \pm 0.01$ & $0.12 \pm 0.01$ \\
Liver & $1151 \pm 63^{* *}$ & $1809 \pm 45^{* *}$ & $1770 \pm 94$ & $2.04 \pm 0.09$ & $2.24 \pm 0.10$ & $2.16 \pm 0.11$ \\
Kidney & $244 \pm 23$ & $193 \pm 7$ & $212 \pm 18$ & $0.44 \pm 0.05^{* *}$ & $0.24 \pm 0.01^{* *}$ & $0.25 \pm 0.01$ \\
Heart & $206 \pm 13^{* *}$ & $273 \pm 9^{* *}$ & $289 \pm 20$ & $0.36 \pm 0.02$ & $0.34 \pm 0.01$ & $0.35 \pm 0.01$ \\
Thymus & $55 \pm 7^{* *}$ & $84 \pm 8$ & $115 \pm 17$ & $0.10 \pm 0.01$ & $0.10 \pm 0.01$ & $0.14 \pm 0.01$ \\
Pancreas & $80 \pm 10$ & $93 \pm 4$ & $87 \pm 8$ & $0.14 \pm 0.01$ & $0.12 \pm 0.01$ & $0.10 \pm 0.01$ \\
Adrenals & $4.0 \pm 0.4$ & $4.7 \pm 0.2$ & $4.6 \pm 0.3$ & $7.3 \pm 0.9$ & $5.8 \pm 0.4$ & $5.6 \pm 0.6$ \\
Thyroids $^{1}$ & $5.5 \pm 0.6$ & $6.1 \pm 0.4$ & $6.6 \pm 0.9$ & $9.8 \pm 1.1$ & $7.5 \pm 0.5$ & $8.1 \pm 0.7$ \\
Parathyroids $^{2}$ & $0.08 \pm 0.01^{* *}$ & $0.13 \pm 0.01^{* *}$ & $0.20 \pm 0.04$ & $1.35 \pm 0.20^{* *}$ & $1.62 \pm 0.10$ & $2.29 \pm 0.40$ \\
\hline
\end{tabular}

Values are mean \pm SEM

** $p<0.01$ based on ANOVA

1 relative weight $10-3$

2 relative weight $10-4$

\section{Renal morphology}

The kidneys of the $\mathrm{Al}(\mathrm{OH})_{3}$-pigs were somewhat enlarged with a markedly light color. A distension of the renal tubules was found histologically in these animals, with focal degenerative changes of the tubular epithelial cells. The lesions were predominantly localized to the juxtamedullary part of the kidney cortex but were not restricted to specific regions of the nephron. Cellular and granular debris was often found, especially in the collecting tubules (Fig. II a, Fig. II b). In four of the $\mathrm{Al}(\mathrm{OH})_{3}$ animals a prominent tubular mineralization was associated with the degenerative changes (Fig. II c). Marked mineral deposits of the nuclear membrane, in addition to granular deposits in the cytoplasm, was observed and a slight mineralization of Bowman's membrane of glomeruli was occasionally seen (Fig. III a and III b). These morphological changes could not be observed in the $\mathrm{A} \mathrm{PO}_{4}$ or control groups.

\section{Discussion}

In the present study, growing pigs given $\mathrm{Al}(\mathrm{OH})_{3}$ developed severe hypophosphatemia, hypercalcemia and a decrease in 2,3diphosphoglycerate (2,3-DPG) in their erythrocytes. The growth rate was retarded and pathological changes appeared in the kidneys, which were enlarged. These alterations were not observed in pigs treated with $\mathrm{AlPO}_{4}$ or in untreated control animals.

The major finding was the hypophosphatemia. The main cause for the phosphate depletion was certainly the $\mathrm{Al}(\mathrm{OH})_{3}$ supplement in the feed which decreased the availability of phosphate. Dietary phosphate deprivation affects renal reabsorption of phosphate in the proximal tubules (Dousa \& Kempton 1982), and urinary excretion of phosphate ceases. This process is normally regulated by a number of mechanisms ( $\mathrm{Pa}$ storiza-Munos et al. 1983). It should be remembered that phosphate requirements are greater in growing, as in this experiment, 
than in mature animals (The nutrient requirements of Farm livestock No 3. Pigs 1981). Rapid growth may induce signs of phosphate depletion even when the amount of phosphate in the diet is in accordance with the recommendations (Brautbar et al. 1979), and it can be suggested that, to some extent, growth rate determines the degree of phosphate depletion. Taken together, diminished availability of phosphate, in addition to high phosphate need during growth, most probably were responsible for the severe hypophosphatemia seen in the present study. This concept is supported by the studies of Lee et al. (1980) on hypophysectomized rats; these animals did not grow and, interestingly enough, developed neither hypophosphatemia nor hypercalcemia when fed a diet poor in phosphate.

The retarded growth of the hypophosphatemic pigs might be the result from different causes. The hypophosphatemia itself and also the anorexia and concomitant decrease in feed intake, obvious in these pigs, might have contributed. Phosphate depleted dogs, as our $\mathrm{Al}(\mathrm{OH})_{3}$-pigs, lost their appetite and became inactive (Fuller et al. 1978). The anorexia rapidly disappeared during the repletion period. Anorexia and retarded growth are well documented in studies of phosphate depleted rats (Day \& McCollum 1939, Davis et al. 1979, Schwarz et al. 1985). Hypercalcemia was observed in the $\mathrm{A} 1(\mathrm{OH})_{3}$ fed pigs but not in the two normophosphatemic groups. This confirms earlier findings in rats (Stoerk \& Carnes 1945, Lee et al. 1977) and dogs (Coburn \& Massry 1970, Freeman \& McLean 1941). The hypophosphatemic hypercalcemia is in part related to the effects of hypophosphatemia on the synthesis of 1,25 dihydroxycholecalciferol (calcitriol) (Dominguez et al. 1976).

The relative weight of the parathyroids was decreased in our hypophosphatemic pigs, although no correlation was noted between the organ weight and serum calcium. It is documented that the relative weight of an organ decreases with increasing live weight (Pond \& Maner 1984) and hence a higher relative parathyroid weight should have been expected. The decreased weight could possibly be attributed to a suppressive effect of the hypercalcemic state, which in turn could be explained by increased 1-alpha-hydroxylase activity in the kidneys, as demonstrated by Tanaka \& DeLuca (1973) in rats and in the chicken (Bar \& Wasserman 1973) and thus also a result from increased bone resorption.

The lowering of 2,3-DPG in erythrocytes confirms findings in man where a similar decrease, including ATP, was observed during hypophosphatemia (Lichtman et al. 1971).

The oxygen delivery to tissues is diminished when 2,3-DPG decreases due to increased oxygen affinity to hemoglobin. This in turn may have consequences for aerobic utilization of substrates in muscles and liver (Rajan et al. 1973). The lowered 2,3-DPG in the present study indicates that the hypophosphatemia obtained was severe enough to induce a decreased concentration of organic phosphate compounds in the pig erythrocytes.

The kidneys from the hypophosphatemic pigs were enlarged compared to the normophosphosphatemic pigs. The increased kidney weight as a result of long-lasting induced hypophopshatemia is in agreement with earlier findings. (Filer et a. 1966). Histological examination was not performed in that study but the changes were characterized as hypertrophy.

In a similar experiment the histological changes found in the enlarged kidneys were described as a chronic diffuse nephritis with distension of the glomerular spaces and uriniferous tubules with presence of a granular debris. (Aubel et al. 1936). 
L. Håglin, B. Essén-Gustavsson, A. Kallner, A. Lindholm, S. Reiland and H. E. Sjöberg: Hypophosphatemia induced by dietary aluminium hydroxide supplementation in pigs: Effects on growth, blood variables, organ weights and renal morphology.

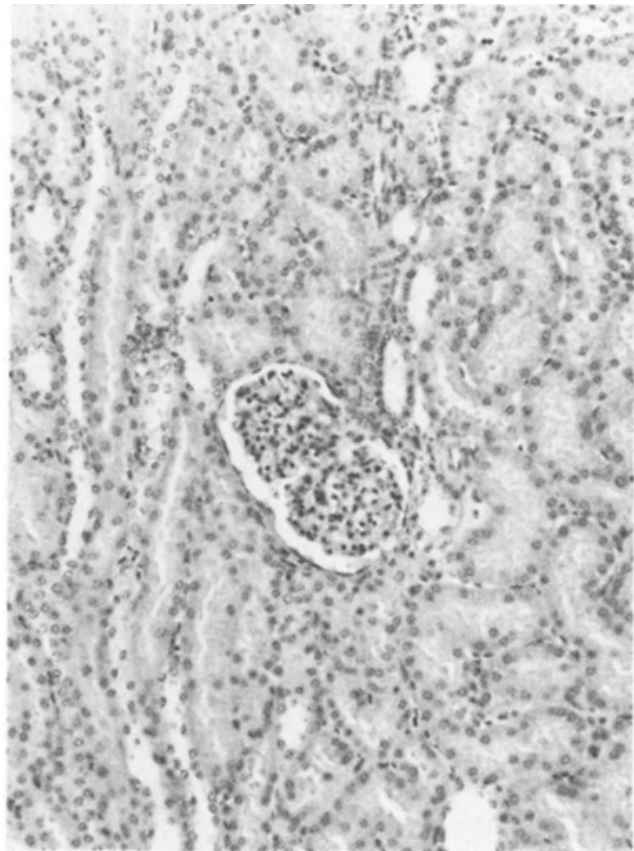

Figure 2a. Histologic section from the juxtamedullary cortical part of the kidney from an untreated control pig. Normal appearance of glomerulus and tubules. $\mathrm{H} \& \mathrm{E} \times 320$.

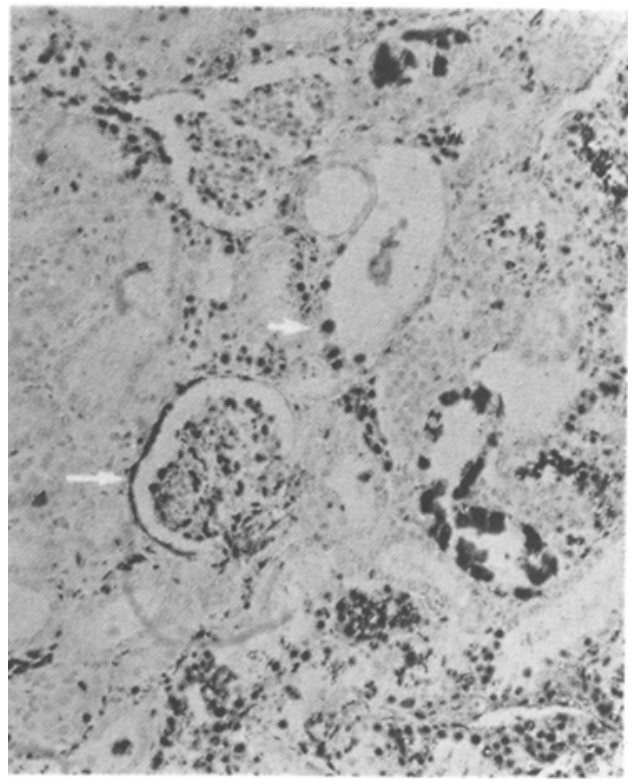

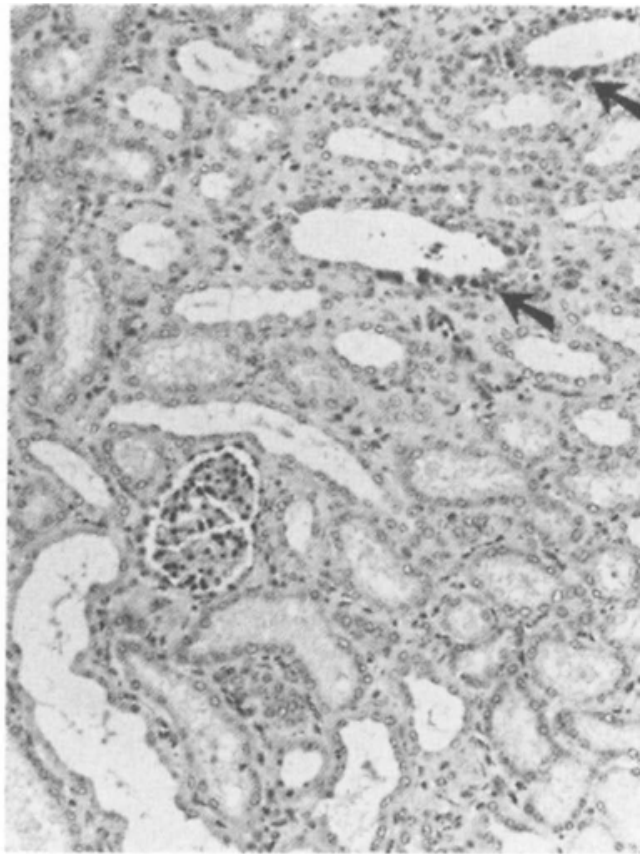

Figure 2b. Histologic section from the same part of the kidney of a pig given $\mathrm{Al}(\mathrm{OH})_{3}$ in the feed. Nephrotic changes with distension of the tubules. Degeneration of epithelial cells (arrows) and presence of a granular debris in some of the tubules. H\&E $\times 320$.

Figure 2c. Same histologic section as in Fig 2b, but stained with the Van Kossa method for mineral $(\mathrm{Ca} / \mathrm{P})$. Black colour indicates positive reaction. Notice mineralization associated with nuclear membrane of tubular cells (small arrow) and of Bowmans capsule of the glomerulus (long arrow). Van Kossa $\times 320$. 


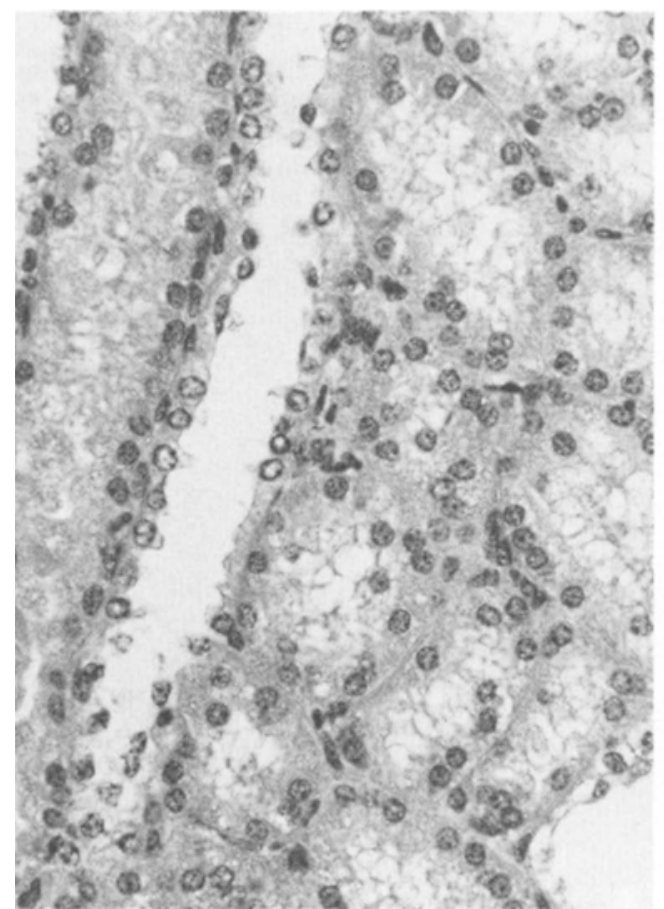

Figure 3a. Close-up view from the same section as in Fig 2a. Normal appearance of tubular epithelium in control pig. $\mathrm{H} \& \mathrm{E} \times 800$.

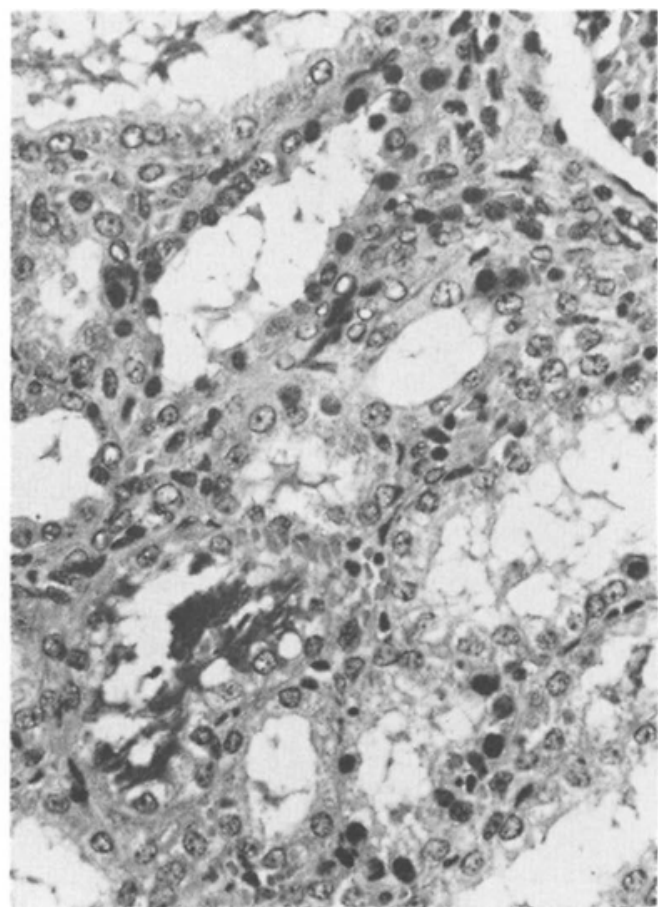

Figure 3b. Close-up view from the same section as in Fig $2 b$. Occurence of degenerated tubular epithelial cells with darkly stained nuclei and mineralized debris in distended tubules of pig given $\mathrm{Al}(\mathrm{OH})_{3}$ in the feed. H\&E $\times 800$. 
In the present study, the changes were obviously of a nephrotic type with changes principly in the cortical juxtamedullary and collecting tubules with nephrocalcinosis. Only incidental inflammatory changes of a minimal degree were found, not considered to contribute to the renal enlargement. There was no histological evidence of a true renal hypertrophy. Therefore the major part of the enlargement was probably caused by tubular dilation and a possible increase of water content.

The tubular injury might be a result of the secondary hypercalcemia since hypercalcemic nephropathy is known to occur with polyuria and thus resistance to vasopressin. Another possible mechanism might be a rhabdomyolysis as described in hyperalimented hypophosphatemic dogs (Knochel et al. 1978). However no evidence for myoglobinuria was observed in our pigs.

Severe hypophosphatemia impairs bicarbonate reabsorption (Emmett \& Seldin 1978) which may result in an increase in $\mathrm{pH}$ in the distal tubules and this alteration, in turn, might also contribute to the metastatic mineralization observed. However, this mechanism has never been confirmed by other investigators.

The absolute weight of the thymus was decreased in the hypophosphatemic pigs. It is, however, difficult to dissect the thymus in pigs as it has a cervical and a thoracic portion and further studies are needed to evaluate the thymic response to hypophosphatemia. If a atrophy of the thymus was to be found with a possible decrease in thymic function, it might offer an explanation for the impaired resistance to infections in the hypophosphatemic state (Knochel 1981). It is of interest in this connection that pigs in a state of chronic stress had a significantly decreased thymus weight (Martinsson et al. 1978).
It is concluded that the addition of $\mathrm{A} 1(\mathrm{OH})_{3}$ to the diet of growing pigs resulted in a severe hypophosphatemia accompanied by hypercalcemia and a decrease of 2,3-diphosphoglycerate in erythrocytes. In addition, retarded growth, a decrease in parathyroid and increase in kidney weight as well as nephrosis of the kidneys was observed.

\section{Acknowledgement}

We gratefully acknowledge support from Laboratoires Biothérax, France and Astra Medical AB, Sweden.

\section{References}

Armitage P: Statistical Methods in Medical Research 3:d ed. Blackwell Scientific Publications, Oxford 1974.

Aubel C E, Hughes J S, Lienhardt H F: The effects of low-phosphorus rations on growing pigs. J. Agr. Res. 1936, 52, 149-159.

Bar A, Wasserman $R H$ : Control of calcium absorption and intestinal calcium-binding protein synthesis. Biochem. Biophys. Res. Comm. 1973, 54, (1), 191-196.

Brautbar $N$, Lee DN B, Coburn JW, Kleeman C R: Normophosphatemic phosphate depletion in growing rat. Amer. J. Physiol. 1979, 236, E283288.

Coburn $J W$, Massry $S G$ : Changes in serum and urinary calcium during phosphate depletion: Studies on mechanisms. J. clin. Invest. 1970, 49, 1073-1087.

Davis J L, Lewis S B, Schultz TA, Kaplan R A, Wallin $J D$ : Acute and chronic phosphate depletion as a modulator of glucose uptake in rat skeletal muscle. Life Sciences 1979, 24, 629-632.

Day $H G$, McCollum $E V$ : Mineral metabolism, growth, and symptomatology of rats on a diet extremely deficient in phosphorus. J. Biol. Chem. 1939, 130, 269-283.

Dominguez $J H$, Gray $R W$, Lemann J: Dietary phosphate deprivation in women and men. Effects on mineral and acid balances, parathyroid hormone and the metabolism of 25-OH-Vitamin D. J. Clin. End. Metab. 1976, 43, 1056-1068. 
Dousa T P, Kempton S A: Regulation of renal brush border membrane transport of phosphate. Mineral Electrolyte Metab. 1982, 7, 113-121.

Emmett $M$, Seldin $D W$ : Disturbances in acid-base balance during hypophosphatemia and phosphate depletion. Adv. exp. Med. Biol. 1978, 103, 313-325.

Ericson A, De Verdier C H: A modified method for the determination of 2.3-diphosphoglycerate in erythrocytes. Scand. J. clin. Lab. Invest. 1972, 29, 85-90.

Filer $L J$, Churella $H$, Knauff $R$, Vaughan $O W$ : Effects of dietary calcium, phosphorus, and strontium on growth, organ weights and bone composition of miniature swine. In: Swine in biomedical research. Eds. Bustad, L. K., McClellan \& M. P. Burns. Battelle Memorial Institute Pacific Northwest Laboratory Richland, Washington 1966, p. 151-162.

Fitzgerald F: Clinical hypophosphatemia. Ann. Rev. Med. 1978, 29, 177-189.

Freeman $S$, McLean $F$ C: Experimental rickets. Blood and tissue changes in puppies receiving a diet very low in phosphorus, with and without vitamin D. Arch. Pathol. 1941, 32, 387-408.

Fuller T J, Nichols $W W$, Brenner B J, Peterson J C: Reversible depression in myocardial performance in dogs with experimental phosphorus efficiency. J. clin. Invest. 1978, 62, 1194-1200.

Goldenberg H, Fernandez A: Simplified method for the estimation of inorganic phosphorus in bodyfluids. Clin. Chem. 1966, 12, 871-882.

Jacob H S: Severe hypophosphatemia. A previously ignored cause of cellular dysfunction. West. J. Med. 1975, 122, 501-502.

Knochel J P: Hypophosphatemia. West. J. Med. 1981, 134, 15-26.

Knochel J P: Models of hypophosphatemia and phosphate depletion. Adv. exp. Med. Biol. 1982, 151, 191-198.

Knochel $J P$, Barcenas $C$, Cotton $J$, Fuller $T J$, Haller $R$, Carter $N W$ : Hypophosphatemia and Rhabdomyolysis. J. clin. Invest. 1978, 62, 12401246.

Koch ME, Mahan D C: Biological characteristics for assessing low phosphorus intake in growing swine. J. Anim. Sci. 1985, 60, 699-708.
Lee D B N, Brautbar $N$, Walling $M W$, Silis $V$, Carlson $H E$, Grindeland $R E$, Coburn $J W$, Kleeman $C R$ : Role of growth hormone in experimental phosphorus deprivation in the rat. Calcif. Tissue Int. 1980, 32, 105-112.

Lee $D B N$, Brautbar $N$, Walling $N W$, Carlsson $H E$, Golvin $C$, Coburn $J W$, Kleeman $C R$ : The biochemical indices of experimental phosphorus depletion (PD): a re-examination of their physiological implications Adv. exp. Med. Biol. 1977, 103, 381-394.

Lichtman M A, Miller D R, Cohen J, Waterhouse C: Reduced red cell glycolysis, 2,3-DPG and adenosine triphosphate concentration and increased hemoglobin-oxygen affinity caused by hypophosphatemia. Ann. Int. Med. 1971, 74, 562-568.

Martinsson K, Ekman L, Löfstedt M, Figueiras H, Jönsson $L$ : Organ weights and concentration of zinc in different tissues of wasting pigs and pigs with regional ileitis. Zbl. Vet. Med. A, 1978, 25, 570-578.

Pastoriza-Munos E, Mishler D R, Lechene C: Effect of phosphate deprivation on phosphate reabsorption in rat nephron: role of PTH. Amer. J. Physiol. 1983, 244, 140-149.

Pond W G, Maner J H: Swine production and nutrition: Animal science textbook series. Publ. West Port, Conn. AWI. 1984.

Rajan S, Levinson R, Leevy C M: Hepatic hypoxia secondary to hypophosphatemia. Clin. Res. 1973, 21, 521.

Ray Sarkar B C, Chauhan U P S: A new method for determining micro quantities of calcium in biological materials. Anal. Biochem. 1967, 20, 155166.

SAS: SAS users guide: Statistics, version 5 edition, SAS Institute Inc, Cary, N. C., USA, 1985.

Schwarz K B, Zimmerman D C, Alpers D H, Avioli $L \quad V$ : Gender differences in antacid-induced phosphate deprivation in rats. Gastroenterology 1985, 89, 313-320.

Silvis S E, Paragas $P$ V: Fatal hyperalimentation syndrome: Animal studies. J. Lab. clin. Med. 1971, 78, 918-930.

Spencer $H$, Kramer L, Norris $C$, Osis D: Effect of small doses of aluminum-containing antacids on calcium and phosphorus metabolism. Amer. J. clin. Nutr. 1982, 36, 32-40. 
Stoerk $H C$, Carnes $W H$ : The relation of the dietary $\mathrm{Ca}: \mathrm{P}$ ratio to serum $\mathrm{Ca}$ and to parathyroid volume. J. Nutr. 1945, 29, 43-50.

Tanaka Y, De Luca H F: The control of 25-hydroxyvitamin D metabolism by inorganic phosphorus. Arch. Biochem. Biophys. 1973, 154, 566-574.

Theiler A, Green $H$ H: Aphosphorosis in ruminants. Nutr. Abs. Rev. 1932, 1, 359-385.

The nutrient requirements of Farm livestock No 3: Pigs. Technical reviews and summaries. Agricultural research Council. London, England 1981.

\section{Sammanfattning}

Hypofosfatemi hos gris genom tillägg av aluminiumhydroxid: effekter på tillväxt, blodvariabler, organvikter och njurmorfologi.

Tjugofyra grisar, 13-14 veckor gamla, studerades under en tio veckor lång experimentperiod. Grisarna delades slumpvis in i tre grupper. Två grupper utfo- drades med ett kommersiellt foder, tillsatt lösning av, antingen aluminium-hydroxid $\left(\mathrm{A} 1(\mathrm{OH})_{3}\right.$ eller aluminium-fosfat $\left(\mathrm{A} \mathrm{PO}_{4}\right)$. En tredje grupp utgjorde kontroller. Ungefär samma totala mängd aluminium tillfördes vardera experimentgruppen. Efter tre veckor utvecklade de $\mathrm{A} 1(\mathrm{OH})_{3}$ behandlade grisarna hypofosfatemi, och en genomsnittlig sänkning av serumfosfat med $60 \%$ minskad tillväxthastighet och lägre koncentration av 2.3-difosfoglycerat $\mathrm{i}$ röda blodkroppar än kontrollerna. Hyperkalcemi utvecklades i $\mathbf{A l}(\mathrm{OH})_{3}$-gruppen under de första sex veckorna, medan $\mathrm{A} \mathrm{PO}_{4}$-grisar och kontroller inte fick vare sig hypofosfatemi eller hyperkalcemi. Vid obduktionen fann man ökad relativ njurvikt och morfologiska tecken på tubulär skada med förkalkning. Några likartade förändringar kunde inte observeras $i$ $\mathrm{A} \mathrm{PO}_{4}$-gruppen och det fanns inte några avvikelser $\mathrm{i}$ organvikter jämfört med kontrollgruppen.

(Received September 2, 1987).

Reprints may be requested from: Lena Håglin, Fack 10, Regionsjukhuset, S-90185 Umeå, Sweden. 
